\title{
ISOLATION OG SINDSSYGDOM \\ - VRIDSLØSELILLE FORBEDRINGSHUS 1859-1873
}

\section{AF PH.D. Peter ScharfF Smith}

Influenced by the breakthrough of the modern penitentiary in America, a thorough reform of the Danish prison system was decided upon in 1842. Two modern penitentiaries were planned and constructed, one based on the so-called Auburn model and the other on the Pennsylvania model. The latter, Vridsløselille, operated as a panopticon facility where constant observation and total isolation were the orders of the day. Even the prison's church and schoolrooms were constructed panoptically, with small wooden boxes within which each prisoner was isolated.

This article demonstrates how this dramatic regime of total isolation influenced the prisoners. An analysis of Vridsløselille's archive from 1859-1873 suggests that inmates suffered a wide variety of symptoms caused by their isolation, from physical hardships like weight loss, to severe psychological problems such as hallucinations, depression and paranoia. Several inmates developed regular insanity.

By 1867, the problems were so obvious that Vridsløselille's director published a book severely criticising the practise of total isolation. In the political process that followed, it was decided to switch to the so-called progressive system in the Danish prisons. This, however, had no influence on the regime of isolation. In fact, Vridsløselille penitentiary continued to use total isolation until the 1930s - long after its practice had been abandoned in most other countries. ${ }^{*}$

I 1866 ankom den 18-årige sjællandske tjenestekarl Henrik Nielsen til Vridsløselille forbedringshus, der var åbnet blot syv år tidligere som landets første isolationsfængsel opført efter det såkaldt Pennsylvania-system. Henrik Nielsen var dømt til fem års forbedringhus for tredje gang begået tyveri og indbrud og havde altså været fængslet tidligere. Den 18-årige var aldeles sund ved indsættelsen og var af en blød og letbevægelig natur. Som så mange andre kriminelle havde han haft en forsømt barndom, som søn af fattige husmandsfolk. Men sjællænderen var jo i hvert fald ikke uvant med fængselslivet, og de første $1 \frac{1}{2} 2$ år i Vridsløselille passerede tilsyneladende også fint. Den indsatte tog eksempelvis ni pund på, hvor mange andre havde problemer med vægttab. Men herefter begyndte tingene at gå skævt. Man bemærkede, at den tidligere tjenestekarl hallucinerede, særligt hvad hørelsen angik. Han mente, at man nærede uvilje mod

\footnotetext{
* Title in English: Isolation and Insanity - Vridsløselille Penitentiary 1859-1873. Original in Danish.
} 
ham, og at fængslets betjente ønskede at skade ham. Henrik Nielsen var i det hele taget meget sky og angst. I øvrigt observerede fængslets personale, at den indsatte i sin celle i høj grad hengav sig til masturbation.

Herefter tildelte man den unge mand arbejde i det fri, en foranstaltning der ganske vist stred mod cellefængslets principper. Men den ønskede bedring indtrådte aldrig for alvor. Tværtimod blev fangen nu både genstridig og ondskabsfuld. Derfor måtte han genindsættes i sin celle, hvor en fuldstændig begrebsforvirring indtrådte. Derefter flyttede man Henrik Nielsen til Østifternes Sindssygesanstalt i Vordingborg.

Ved overførslen til Vordingborg anførte fængselslæge dr. Wiberg, at den unge mand udover de allerede anførte problemer også led af søvnløshed, talte med sig selv, var sky i blikket, havde et rødligt ansigt og en noget accelereret puls. Endvidere var han tynget af en melankolsk stemning, der ytrede sig ved jævnlige suk. Sammenfattende konkluderede Wiberg, at sjællænderens tilstand ved afleveringen til sindssygeanstalten først og fremmest var præget af angst.

I Vordingborg beskrev man Henrik Nielsen som legemlig sund, omend lettere "kongestioneret" (lidende af "blodtilstrøming") og klagende over hovedpine. Nielsens ansigtsudtryk var stift, ubevægeligt og lidt angstfuldt. Hans blik var i reglen sænket, og pupillerne var meget udvidede og sløve i bevægelserne. Endvidere konstaterede man, at patienten havde en slap holdning, og var meget langsom og energiløs i sine bevægelser. Ved ankomsten til anstalten var Henrik Nielsen rolig, men særdeles konfus og i øvrigt viljeløs. Tilsyneladende forstod han overhovedet ikke, hvor han var, men havde allerede glemt rejsen til Vordingborg og troede sig anbragt $i$ et fængsel. Nielsen svarede ikke på spørgsmål og skjulte sit ansigt mellem armene. Allerede dagen efter livede han dog op og kunne plukke tovværk med de andre patienter. Udover jævnligt at klynke over hovedpine fik den tyveridømte det hurtigt bedre, viste ikke tegn på hallucinationer og var ikke oppositionslysten under sit ophold i Vordingborg. Den 23. juni 1868 udskrevedes han som helbredt og overflyttedes til straffeanstalten i Christianshavn for at udstå resten af sin straf i fællesskab uden at være underlagt isolation.'

\section{Det moderne fængselsvæsens gennembrud og den totale isolation i Vrids- loselille}

Fra og med 1600-tallet eksisterede fængslet som en relativt etableret institution side om side med periodens blodige korporlige straffesystem. Først i England fra 1770 'erne og siden hen i USA fra 1790 'erne fandt nye fængselsprincipper fodfæste. Omdrejningspunkt var en ekstrem disciplin og isolation af fangerne samt en udbredt tro på, at kriminelle ikke blot skulle afskrækkes, men ligeledes både kunne og burde forbedres. En årrække senere fik de moderne fængsler deres egentlige gennembrud i USA og dannede i den amerikanske version skole for hele den vestlige verden. I 1820'erne konstrueredes det såkaldte Auburn- 
system i Auburn fængslet i staten New York og få år efter det såkaldte Pennsylvania-system i Cherry Hill fængslet i Philadelphia - den institution hvorefter Vridsløselille kopieredes. Begge systemer foreskrev isolation, disciplin og hårdt arbejde. Auburn-systemet tillod dog de indsatte at arbejde i fællesskab om dagen, men under fuldstændig tavshed. Ingen kommunikation var tilladt. I Philadelphia ønskede man ikke på nogen måde at gå på kompromis med isolationsidealet, og fangerne tilbragte al deres tid i cellen, hvor også arbejdet fandt sted. Her skulle den indsatte vende tankerne indad, møde Gud, angre sine forbrydelser og træde tilbage i samfundet som en renset kristen medborger. En stærk religiøsitet var således et nøgleord i den planlagte forbedringsproces. ${ }^{2}$

En hæftig strid udviklede sig i USA mellem fortalerne for de to systemer. Auburnmodellen sejrede, for så vidt at langt de fleste amerikanske stater fulgte denne model, omend flere sydstater ikke fulgte med de nymodens planer. Pennsylvania-systemet vandt imidlertid den største opbakning i Europa, hvor mange nationer forsøgte sig med denne model. Det gjaldt eksempelvis Norge, Sverige og Danmark. Dermed formedes et fængselsvæsen, der kom til at afløse de gamle tugthuse. Således etableredes et nyt straffessystem, der lå endog utroligt fjernt fra de brutale offentlige afstraffelser, der havde præget 16-1700-tallet. ${ }^{3}$

De to amerikanske systemer nåede den danske presse og debatteredes $\mathrm{i}$ 1830 'erne. Et egentligt politisk gennembrud kom dog først i 1840, hvor den såkaldte fængselskommission blev nedsat. I 1842 afgav kommissionen betænkning, og flertallet anbefalede Pennsylvania-systemet som model for dansk fængselsreform, mens et mindretal advokerede for Auburn-modellen. Resultatet blev, at man ville opføre fængsler efter begge principper. I 1853 stod tugthuset $i$ Horsens færdigt, bygget efter Auburn-systemet, mens forbedringhuset i Vridsløselille åbnede 1859 som en pennsylvansk straffeanstalt. I sidstnævnte skulle man forbedre de mindre grove forbrydere, der ikke var aldeles tabt i moralsk henseende. Man fulgte systemforskrifterne loyalt og indførte den totale isolation. Selv ved transport rundt i fængslet skulle indsatte bære masker for ikke at kunne se hinanden. De eneste brud på ensomheden bestod i korte besøg af blandt andre fængselspræsten og fængselslæreren samt i gudtjeneste og undervisning. Både fængslets kirke og skole var imidlertid - som hele fængslet - indrettet på panoptisk vis, som et amfiteater, hvor alle indsatte sad isolerede i små bokse, alt imens præsten og skolelæreren "prædikede" fra et højtsvævende "alter". Det var således tanken, at man skulle kunne afsone flere års straf i Vridsløselille uden nogensinde at se sine medfangers ansigtstræk eller konversere med dem. ${ }^{4}$

I det følgende vil der blive set nærmere på, hvordan isolationen og ensomheden i Vridsløselille påvirkede de indsatte mentalt. Udviklingen vil blive fulgt fra fængslets åbning i 1859 til 1873, hvor det såkaldte progressive system indførtes $i$ alle landets fængsler.

Egentlig burde der ikke have været væsentlige sundhedsmæssige problemer i 
Vridsløselille. Fængslet blev således fremhævet som den fremmeste danske straffeanstalt, når det kom til hygiejne og renlighed. ${ }^{5}$ Med vandklosetter, enkeltmandsceller og gasvarme var der sørget for alt det, der manglede i 1700-tallets gamle tugthuse. Der var også indrettet en sygestue, hvor fængslets læge kunne indlægge de fanger, der ikke kunne behandles i cellerne. Sidst men ikke mindst, så havde de indsatte ifølge reglementet altid ret til at hidkalde lægen, og eventuelle sygdomme burde således opdages hurtigt.

I øvrigt havde spørgsmålet om isolation og sindssygdom været debatteret allerede under fængselskommissionens arbejde i 1840-42. Det totale afsondringssystem blev dengang - med baggrund i amerikanske diskussioner om de pennsylvanske fængsler - anklaget for at forårsage mentale forstyrrelser hos de indsatte. Fængselskommissions majoritet anførte imidlertid kort og godt, at de, der havde undersøgt anklagerne vedrørende tilfælde af sindssygdom "grundigt", havde modbevist dem. ${ }^{6}$ Man behøvede derfor ikke at frygte for de danske fangers mentale tilstand. Som de mange tusinde borgere, der passerede gennem Vridsløselilles porte, måtte sande, så var det en konklusion, der desværre ikke skulle vise sig at holde stik.

\section{Problemerne begynder i Vridsløselille}

Vridsløselille modtog det første hold fanger i december 1859, og forbedringen kunne begynde. I løbet af 1860 - fængslets første år - er det imidlertid svært at følge de indsattes sundshedstilstand nøje. Først i 1861 besluttede man, at fængslets læge, dr. Wiberg, skulle lave kvartals- og årsrapporter over sundhedstilstanden i fængslet.? Endvidere var det yderst sjældent, at man bogførte diskussioner af personsager ved embedsmændendes ugentlige møder. ${ }^{8}$

Allerede ved det første ugentlige møde blandt fængslets embedsmænd bemærkedes det dog, at fange nr. 30 muligvis var i en mindre stærk mental tilstand. Den pågældende havde ellers haft en god sundhedstilstand ved ankomsten til fængslet. Problemerne fortsatte imidlertid, og allerede ugen efter diskuteredes sagen igen. Man vedtog at forlænge nr. 30's gårdture og satte ham i øvrigt til trætøffelarbejde. ${ }^{9}$ Den første disposition vidner om, at man anså fangens tid $\mathrm{i}$ cellens ensomhed for at være et problem. De forlængede gårdture er endvidere det første eksempel på, hvordan man brød med reglementet for at modvirke isolationens indflydelse på den indsatte. Den slags pragmatiske foranstaltninger skulle senere vise sig at få et langt større omfang.

Men umiddelbart fremstod nr. 30 som et særtilfælde. Ifølge fængslets papirer optrådte der i hvert fald ingen væsentlige problemer i den næste tid. Den 9. marts fandt man dog anledning til at skrive et par ekstra linier i mødeprotokollen. Man bemærkede at "Kraghs mentale tilstand" gjorde nøje observation nødvendig, og det besluttedes at give ham "så megen omgang og adspredelse som muligt". Endvidere ændrede man Kraghs diæt og sørgede for, at han havde lys i sin celle om natten. ${ }^{10}$ Der var med andre ord tale om dispositioner, der skulle 
både afbøde og indskrænke ensomheden.

I oktober henledte embedsmænd videre opmærksomheden på indsatte Rasmussens sjælelige tilstand, og senere samme måned blev "enkelte fangers kraftløshed" debateret. " En tilstand, der opstod, trods den ordentlige og nærende kost. Den 4. januar 1861 gjorde inspektør Bruun endvidere opmærksom på, at to indsatte var trykkede af ensomheden. Bruun anbefalede bl.a. undervisning i det ene tilfælde. ${ }^{12}$

\section{Fængselslægens kvartals-rapporter}

I april 1861 afleverede fængselslægen dr. Wiberg sin første rapport. I løbet af april, maj og juni havde Wiberg haft 22 fanger indlagte på fængslets sygeafdeling, hvoraf han regnede 20 for helbredte. Sygdommene varierede fra eksempelvis skørbug, fnat, lændesmerter og forstoppelse til det mere særprægede som "Svulst i Penis". Endvidere led én indsat af krampe, en anden af besvimelse, mens en tredje fik den lidt specielle diagnose "Svcekkelse". Herudover var 57 fanger blevet behandlet for mindre sygdomme, såsom forkølelse og orm. Ifølge rapporten var der ingen tegn på, at flere indsatte var mentalt forstyrrede. Wiberg konkluderede sammenfattende, at sundhedstilstanden i det hele var tilfredstillende. ${ }^{13}$

Kvartalet efter så sygdomsbilledet ikke væsentligt anderledes ud, omend antallet af fnattilfælde var steget noget, mens eksempelvis to meldte om "Trykken for Brystet" og én klagede over hovedpine. ${ }^{14} \mathrm{I}$ oktober optrådte diagnoserne "Mathed" og "Søvnløshed" hver én gang, mens to havde hovedpine. Særligt interessant er det imidlertid, at Wiberg afsluttede sin rapport med at adressere tilfælde af søvnløshed i al almindelighed. Fængselslægen bemærkede, at denne tilstand "af og til betraffes $i$ Forskningen af Fangenskabet", men forsikrede, at problemet hurtigt kunne løses ved "beroligende Omgang og Midler" uden fare for de indsattes legemlige og åndelige befindende. ${ }^{15}$ Alligevel er Wibergs observation interessant - ikke mindst set i forlængelse af, at man som nævnt allerede i løbet af 1860 konstaterede en særlig sløvhed og søvnløshed blandt indsatte. Det var imidlertid ikke noget, Wiberg anså for et større problem. ${ }^{16}$ Under alle omstændigheder var man ifølge rapporterne ikke stødt ind i tilfælde af sindssygdom eller lignende blandt de indsatte.

Leder man videre i fængslets journalsager fortæller de imidlertid en anden historie. I juli 1861 optræder således to tilfælde, hvor Wiberg udtalte sig om enkelte fangers problemer. Nr. 176 H.O. Holse havde vist utvetydige "Tegn paa Sindsforvirring" og led endnu af nervesvækkelse. Fangen kunne simpelthen ikke tåle ensomhed, konkluderede Wiberg, og tilrådede en overflytning til fællesskab. Samme dag forfattede fængselslægen en erklæring om nr. 292 Hans Petersen. Petersen havde haft hallucinationer og var i øvrigt "af et svagligt Udseende". Lægen vurderede også i dette tilfælde, at det var "mindre tilraadeligt" at lade den pågældende forblive i ensomhed. ${ }^{17} \mathrm{I}$ begge tilfælde fulgte man 
lægens råd og lod de to fanger arbejde i fælleskab med visse andre særbehandlede fanger. Igen valgte man fra fængslets side en pragmatisk løsning, der stred mod de oprindelige regulativer.

Man kan undre sig over, hvorfor de to tilfælde ikke optræder i Wibergs almindelige rapportering. Nr. 176 fremdrages endog i sundshedsrapporten omhandlende juli og oktober kvartal pga. "Blodcongestion til Hjernen", men uden henvisning til den sindssforvirring, der ifølge Wiberg jo ellers var så tydelig. En årsag kunne være, at Wiberg eller fængslets ledelse ikke ønskede opmærksomhed omkring den slags problemer. Under alle omstændigheder følte fængselslægen sig kort efter - ved udgangen af 1861 - foranlediget til at konstatere, at cellesystemet "ikke har vist sig at have havt nogen egentlig skadelig Indflydelse". ${ }^{18}$

Ikke desto mindre optrådte diagnosen "Sindsforvirring" for første gang allerede i den næste sundhedsrapport. 14 indsatte havde april til juni 1862 været indlagt på fængslets sygeafdeling, hvoraf to var ramt af sindsforvirring. Nr. 232 var endog undertiden voldsom. Endvidere blev 30 indsatte i perioden behandlet i deres celle, hvoraf én klagede over både hovedpine og angst. ${ }^{19}$ Tre måneder senere fik nr. 232, der bar navnet Hans Jensen, den mere definitive diagnose "Sindssvaghed". Wiberg beskrev sammenfattende, at den pågældende var ankommet til fængslet med "svage Forstands evner", men først omkring påske 1862 havde fået "fixe Ideer". Fangen mente bl.a., at han var selveste Vor Herre. Hans Jensen var endvidere søvnløs og blev senere direkte voldsom. En dag angreb han endog en overbetjent. Wiberg beskrev endvidere, hvordan nr. 232 var meget rød i ansigtet, afmagret og havde et "vildt Blik". Efter at have udstået sin straffetid sendtes han derfor til sindssygeanstalten i Vordingborg. ${ }^{20}$

Lægens henvisning til, at Hans Jensen allerede ved ankomsten var mentalt svagelig, frikendte selvfølgelig cellefængslet og ensomheden. Men Wiberg blev imidlertid modsagt af Vridsløselilles korrespondance. Fra fængslets side tilskrev man således Hans Jensens hjemstavn, i form af Møens herredskontor, med en forespørgsel om netop hans mentale og sjælelige tilstand før fængslingen - utvivlsomt for at undersøge, hvorvidt han var uheldigt disponeret, eller om cellestraffen var årsag til problemerne. Den lokale herredsfoged udførte et større stykke arbejde for at udrede sagen. Han talte med flere af Hans' tidligere arbejdsgivere, hvoraf ingen kunne bemærke "nogen Mangel ved hans sjalelige Tilstand". Herredsfogeden havde i øvrigt selv haft den fængslede under behandling ved to retssager og kunne heller ikke pege på nogle særheder. Hans Jensen var med andre ord normalt fungerende, før han undergik navneforandring til nr. 232 i Vridsløselille. ${ }^{21}$ Den 16. september 1862 blev han tilsyneladende den første indsatte, der overførtes til sindssygeanstalt - men andre skulle følge.

Senere på året løb en anden fange ind i problemer. Der var ifølge Wiberg tale om "en fjollet Person", der viste sig meget ustyrlig. For første gang bogførte lægen i en af sine rapporter, at den pågældende var "uskikket til at udholde Cel- 
lestraf' ${ }^{22}$ Fangen blev dog efter en tid roligere, men ville ikke tale. Når fængslets ansatte henvendte sig til ham, svarede han blot med "et tosset Grin". Derfor, noterede Wiberg tørt i april 1863, var det "paatcenkt at hensende ham til en Sindssygeanstalt". En anden indsat viste samtidig tegn på mental forstyrrelse. Dennes sindsstilstand forværredes de første måneder af 1863, hvorefter han blev opfarende, søvnløs og periodevis tydeligt sindsforvirret.

I det hele taget tog problemerne i Vridsløselille tilsyneladende til nu. Nr. 307, der længe havde arbejdet flittigt som stolemager, blev pludselig træt, søvnløs og mismodig. Endvidere klagede flere over hovedpine samt svimmelhed. ${ }^{23}$

Senere på året - oktober kvartal 1863 - var der pludselig, ud af 17 behandlede på sygeafdelingen, hele fire med diagnosen sindssforvirring, hvoraf to overførtes til sindssygeanstalt. Af de resterende 13 led én af søvnløshed, en anden havde "uroligt Sind" mens en tredje udviste ustyrlighed. Næsten halvdelen af de indlagte havde dermed tilsyneladende isolationssymptomer. ${ }^{24} \mathrm{I}$ øvrigt behandledes en fange i sin celle for "forstyrret Sind", og én indlagdes senere for "fortrykt Sindsstemning". ${ }^{25}$

I Wibergs samlede rapport for finansåret 1863-64 var der eksempler på alt fra sløvhed og mathed til forvirring, hallucinationer og sindssygdom. Diagnoserne varierede tilsyneladende noget, men flere dækkede ved nærmere eftersyn over svære psykiske problemer. Hos en allerede beskrevet indsat var "et tosset Grin" tilsyneladende nok til overførsel til sindssygeanstalt, mens andre fik betegnelsen forstyrret sind, sindsforvirret, galskab eller blot forvirret. En fange var simpelthen "ei rigtig $i$ Hovedet" og blev overført til sindssygeanstalten. Tre led tilsyneladende denne skæbne, mens de fleste blev behandlet i fængslet, nr. 181 bl.a. med spændetrøje. Han led af søvnløshed, hallucinerede og var aldeles sindsforvirret. Herudover var han urenlig, sang, skreg og rev ting i stykker. Flere led af en eller anden form for sløvhed, der tilsyneladende (og af ukendte årsager) kategoriseredes på forskellige måder. Nogle var blot sløve, mens "mathed" og "svcekkelse" var egentlige diagnoser. Endvidere var flere søvnløse. ${ }^{26}$

Under alle omstændigheder stod det efterhånden klart, at et antal fanger blev påvirket mentalt i cellefængslet. Flere blev simpelthen sindssyge. Hvorvidt dette skyldtes ensomheden, ytrede man sig ikke om. Om isolationen i Vridsløselille medførte sindssygdom, var derfor endnu ikke en officiel problemstilling. Alligevel er det klart, at flere af fængslets embedsmænd må have gjort sig tanker i den retning i løbet af fængslets tidlige år. At man eksempelvis forsøgte at begrænse isolationen ved forlængede gårdture, udearbejde m.m., vidner tydeligt om dette. Derudover var det et tilbagevendende problem, at et antal indsatte behandledes for hovedpine, søvnløshed, mathed, depression og angst. Søvnløsheden og nedtrykt sindsstemning optrådte bl.a. hos enkelte sindssyge.

Endvidere tegnede der sig allerede i løbet af perioden frem til 1863 en praksis, hvor åbenlyst sindssyge fanger i første omgang blev søgt særbehandlet, f.eks. ved fællesarbejde, hvorefter flere overflyttedes til regulære sindssygean- 
stalter forskellige steder i landet. Det var en praksis, der blev fulgt og udvidet de følgende år. Sindssygdom i fængslet var i den forstand et etableret problem, men årsagssammenhænge ville man endnu nødigt udtale sig om. I den officielle beretning vedrørende det danske fængselsvæsen omhandlende perioden fra 1858 til 1863 turde man således ikke have en sikker mening om isolationssystemets "Virkning og Indflydelse". ${ }^{27}$

Set i bakspejlet er det måske ikke så underligt, at man tøvede i sine konklusioner. Fangebehandlingen i Vridsløselille udgjorde således i realiteten et gigantisk forsøg. De moderne isolationsfængsler var godt nok på retræten mange steder i udlandet, men set i en national kontekst havde man stort set ingen tidligere erfaringer at holde sig til. ${ }^{28}$ I Vridsløselille var man tydeligvis opmærksom på, at ensomheden kunne udgøre et problem, men man havde ingen væsentlig praktisk erfaring med og viden om isolationens virkning og symptomer. Årsagerne til mental forstyrrelse kunne være mange og individuelle, og man var nødsaget til at lære henad vejen.

Endvidere udgjorde forståelsen af sindsygdom i al almindelighed et usikkert videnskabeligt felt, der gik ind i en rivende udvikling i 1800-tallets sidste halvdel, ikke mindst inspireret af psykiatriens fremvækst. Hvorfor og hvordan isolerede individer blev påvirkede af ensomheden, var med andre ord et åbent spørgsmål såvel for læger og psykiatere som for fængslets ledelse. For den lægefaglige gruppe gjorde det sig endvidere gældende, at de var grebet af tidens videnskabelige trend i form af den såkaldte biologiske determinisme. Særligt i løbet af 1800-tallets sidste halvdel holdt den biologiske tænkning således sit indtog. Hjernen opfattedes som et kompliceret nerveorgan, og psykiatriske symptomer defineredes som forårsaget af forstyrrede cerebrale reflekser. ${ }^{29} \mathrm{Med}$ et fint ord kaldte man denne teoris fortalere for "somatikere". De mente at kun legemet kunne være sygt, og ikke sindet. Årsagen til sindssygdom måtte derfor findes $i$ en biologisk defekt $i$ hjernen, mens sociale forhold var irrelevante. ${ }^{30}$

\section{Flere sindssyge, søvnløse, paranoide, hallucinerende og kraftløse fanger}

I løbet af de næste år greb problemerne om sig, og det blev mere og mere tydeligt, at ensomheden påvirkede de indsatte. I perioden 1863 til 1868 steg antallet af sindssyge mærkbart, hvilket vi skal vende tilbage til nedenfor.

Efter en større gennemgang af Vridsløselilles almindelige journaler, journalsager og sygejournaler forekommer det relevant at opstille følgende kategorier af isolationssymptomer hos fængslets indsatte: 1) Fysiologiske forandringer. 2) Forvirring og manglende koncentrationsevne. 3) Hallucinationer, illusioner og paranoide forestillinger - ændringer i perceptionsevnen. 4) Emotionelle reaktioner og impulsive handlinger - angst, depression og agressivitet. 5) Sløvhed og kraftløshed - stilstand og personlig degeneration. Nedenfor følger enkelte eksempler. 


\section{1) Fysiologiske forandringer}

Det er eksempelvis påfaldende, at mange indsatte i Vridsløselille tabte i vægt. Dette på trods af, at lægen og fængslets øvrige embedsmænd var rimeligt tilfredse med kosten, og at førstnævnte kunne ordinere ekstra kost til fangerne. Alligevel var vægttabene typiske. Fra fængselsvæsenets side konstaterede man i 1868, at "af 1596 Fanger tabte allerede $i$ de 3 forste Maaneder 651 i Voggt, altsa a 41\%". ${ }^{31}$ Af sygejournalerne fremgår vægttabene, der blandt 300 tilfældigt optalte varierede fra nogle få pund til 25 pund. Typisk drejede det sig om mellem 5 og 10 kilo. Flere af disse blev ved løsladelsen beskrevet som "magrere", "meget mager" eller lignende. ${ }^{32}$

\section{2) Forvirring og manglende koncentrationsevne}

Mange indsatte blev beskrevet som forvirrede, hvilket tilsyneladende var en slags fællesbetegnelse for en lang række symptomer. ${ }^{33}$ Hos flere hæftede man sig ligeledes ved en uklar tankegang. ${ }^{34}$

En 21-årig københavner ved navn Emilius fik eksempelvis pludselig nogle religiøse skrupler og ville tale med præsten. Nogle dage senere indtrådte "en mere almindelig Forvirring af Begreber", og Emilius blev bl.a. eksalteret og fløjtede tilsyneladende en del. ${ }^{35}$ En anden indsat blev beskrevet som sindsforvirret, var ofte opløst af gråd, talte uafladeligt om amtmanden og klagede over den synd, der var begået imod ham. ${ }^{36}$ En tredje var tankeløs, åndeligt sløv og havde vrangforestillinger. ${ }^{37}$

\section{3) Hallucinationer, illusioner og paranoide forestillinger - cendringer i percep-} tionsevnen

Det blev ofte rapporteret, at indsatte hallucinerede. ${ }^{38}$ Det var eksempelvis tilfældet med den 19-årige Henrik Nielsen, der hallucinerede særligt på hørelsen. Dette afstedkom paranoide forestillinger, idet han mente, at fængslets betjente efterstræbte ham. ${ }^{39}$ En anden fange hallucinerede ligeledes og fik den ide, at hans stedfader var blevet dræbt på Ladegården, der fungerede som en fattiggård i perioden. Senere blev han aldeles forvirret og overmalede sit gulv med galger og skafotter, hvorefter turen gik til Skt. Hans. ${ }^{40}$

4) Emotionelle reaktioner og impulsive handlinger - angst, depression og agressivitet

Der er talrige eksempler på hvordan indsatte blev grebet af depression og angst. Den tidligere omtalte Henrik Nielsen var således i en "melankolsk Stemning", der ytrede sig ved "jovvnlige Suk". I øvrigt var han sky i blikket, og Wiberg betegnede ham som angst. ${ }^{41}$ En anden var ved løsladelsen " $i$ en meget nedtrykt Sindsstemning for Fremtiden". ${ }^{42}$ Hos nogle blev opførslen direkte aggresiv og truende. Flere blev også beskrevet som ondskabsfulde. F.eks. en 25-årig jyde, der hallucinerede og blev svinsk, ondskabsfuld og uregerlig, hvorefter han blev sendt til en sindssygeanstalt. ${ }^{43}$ 
5) Sløvhed og kraftløshed - stilstand og personlig degeneration

I sundhedsrapporterne fremkom Wiberg - som tidligere nævnt - med flere diagnoser, der kredsede omkring temaet sløvhed. Svækkelse og mathed var ofte blandt de mest repræsenterede sygdomme på sygestuen, som i finansåret 186364 , hvor otte havde været indlagt med førstnævnte. Denne lidelse var sammen med febertilfælde således topscoreren det år. I øvrigt var fire blevet behandlet for svækkelse i deres celler og yderligere fire for mathed. ${ }^{44}$ Det siger sig selv, at der lå mere end blot lidt forbigående sløvhed bag disse diagnoser, eftersom de var årsag til egentlig indlæggelse. Det er også trist at følge mange af de indsatte i Vridsløselilles sygejournaler. En typisk fangeskæbne i denne henseende er nr. 1222, der sad indespærret et halvt år i 1868. Han var 32 år, havde tidligere været hengiven til svir, men var af et normalt helbred ved ankomsten til fængslet. Under afsoningen tabte han otte pund i vægt og var ifølge sygejournalen mat og "medtaget af straffen". Ved løsladelsen beskrev man nr. 1222 som følger: "Bleg Ansigtsfarve, meget afmagret, bekymret og udslaaet af frygt for fremtiden" ${ }^{45} \mathrm{En}$ anden indsat var også rask ved ankomsten, men tabte 17 pund og blev ved frigivelsen betegnet som "Mat og træet" med "slappe Muskler" og et "dårligt og blegt Udseende". ${ }^{46}$

Samlet betragtet stod det sidst i 1860 'erne tilsyneladende klart, at isolationen i Vridsløselille havde omfattende skadevirkninger.

\section{Fængselsinspektøren - en modstander af den totale isolation}

I 1867 udkom Om fuldbyrdelse af Strafarbeide forfattet af ingen ringere end inspektøren for Vridløselille, der samtidig var chef for det samlede danske fængselsvæsen. Heri leverede Frederik Bruun mindre end otte år efter Vridsløselilles åbning en sønderlemmende kritik af forbedringshusstraffen, som den blev ført ud i livet i netop den pennsylvanske institution. Det var først og fremmest isolationen, der stod for skud. Bruun var nået til den "fulde Overbevisning", at isolationsstraf i længere tid medførte "betydelige Farer for Fangens Sundhed i psychisk Henseende". Det var en fare, som Bruun ikke anså "det for muligt at afvende", og som han "ikke noget sted ...[havde]... seet afvendt". ${ }^{47}$

Bruun gik statistisk til værks og beskrev, hvordan sindssygdom var mere udbredt i fællesfængsler end i den frie befolkning, endog hyppigere i cellefængsler end fællesfængsler, og for cellefængslernes vedkommende mere almindelig hvor den absolutte afsondring var gennemført (som i Vridsløselille), end hvor man havde fællesskab i kirke, skole og gård. ${ }^{48}$

Bruun regnede sig herefter frem til, at sindssyge danskere udgjorde $0,108 \%$ af den samlede befolkning. I Vridsløselille var anddelen af sindssyge fra april 1863 til 1867 opgjort til 2,28\%. Herudover forekom der i cellefængslerne ifølge Bruun hyppigere "abnorme Tilstande, der i Reglen ere Forløbere for Sindssygdomme". Med henvisning til bodsfængslet i Christiania fremførtes det, at 
sådanne tilstande bl.a. kunne være hovedcongestioner, hypokondrisk forstemning, søvnløshed med og uden ængstelse, hallucinationer, mistænksomhed, mismod og fikse ideer. ${ }^{49}$ Det er allerede fremført, hvordan lignende diagnoser prægede sundhedsrapporterne fra Vridsløselille.

Inspektøren forsøgte sig også med en mere filosofisk udredning af livet $\mathrm{i}$ fængslet og sindssygdommenes opståen, der i virkeligheden betegnede en revurdering af den ideologi, der lå bag hele det moderne fængselsvæsen. Det var ifølge Bruun utvivlsomt, at cellesystemet påførte de indsatte lidelse, men det var jo også meningen - straffens formål var både afskrækkelse og forbedring. Problemet bestod $\mathrm{i}$, hvordan man forhindrede denne lidelse i at gå ud "over sine Bredder, saa den overvaelder og tilintetgjør".

Den oprindelige tanke var, at den indsattes arbejde i cellen ville gøre nytte ved at sysselsætte tanken og styrke legemet. Men det var ifølge Bruun kun sjældent, at denne mission lykkedes. De fleste skulle lære et uvant arbejde, der ikke interesserede dem, og snart blev til en manual færdighed, der ikke optog tankens kraft - og "Medens Haanden er syselsat, er Tanken ledig; den søger udad, flagrer om $i$ Angstelse og Tvivl, kommer ofte $i$ en skjev Retning og gaaer da $i$ Ensomheden uforstyrret sin Vei". ${ }^{50}$

For nu ikke at lade tanken ganske alene, men i stedet styre den på rette vej, havde fængselsystemet dog sørget for andre hjælpemidler. Først og fremmest en salmebog og det ny testamente, der altid var tilgængelige, samt herudover andre bøger til adspredelse. En stor del af fangerne kunne imidlertid knapt læse eller skrive og havde ifølge Bruun ikke megen gavn af dette. Men her skulle fængslets præst, læreren, lægen, inspektøren og andre embedsmænd naturligvis sætte ind og sørge for daglige besøg. Med dette personale forholdt det sig imidlertid sådan, at de havde dårlig tid. Med en meget optimitisk beregning anslog Bruun, at hver enkelt fange maksimalt kunne tildeles et seks minutters besøg hver dag. I øvrigt var det et problem, at fangerne ofte var på et lavere dannelsestrin end det besøgende personale, hvorfor samtalen ville foregå i en "uvant Sphcere", og fangen ville måske føle sig "mere trcettet end opmuntret derved". Endvidere skulle den ugentlige gudstjeneste samt to til tre timers undervisning om ugen opbygge fangen. ${ }^{51}$

Et andet problem ved ensomheden var ifølge Bruun, at den fremmede de indsattes lyst til at onanere, hvilket vil blive omtalt nedenfor.

Samlet mente Bruun, at det anvendte straffesystem nok kunne få forbryderen til at vende tankerne indad og erkende sin forbrydelse, men herfra var man ikke i stand til at fortsætte forbedringen og skadede ved den benyttede metode snarere de indsatte. Fangen resignerede herefter i ensomheden, følte sig uretfærdigt straffet og mistede tilliden til præsten, læreren og andre, der skulle forbedre ham. Bl.a. derfor ville det aldrig lykkedes at etablere den individuelle behandling, som det var tiltænkt med det pennsylvanske system. Man ville aldrig nå ind til den indsattes sande karakter, og "som Fangen bliver ukjendt for Bestyrel- 
sen, saaledes bliver han det ogsaa for sig selv. Hans Personlighed udviskes, fordi den mangler Leilighed til at udvikle sig". ${ }^{2}$

Bruuns kritik ramte således midt ned i det moderne fængselsvæsens ideologi og foregreb i øvrigt en langt senere forskningsdiskussion. Hvor filosofen Michel Foucault således tager udgangspunkt $i$, at de nye fængsler netop realiserede en individuel behandling, der via en ny rationel magtteknologi formede individet, så anfører sociologen David Garland, at man først etablerede et individualiserende fængselssystem i perioden 1895 til 1914. Foucault tager med andre ord de moderne fængslers ideologiske forskrifter for pålydende, mens Bruun og Garland går bag om reglementerne og ser på praksis i de nye institutioner. Her taler meget - jævnfør Bruuns udlægning - for, at de moderne fængsler trods intentioner om det modsatte skabte et system, der var mere uniformt end individualiserende. Særbehandlingen var således, når alt kom til alt, stærkt begrænset i de panoptiske fængsler. I starten af det 20 'ende århundrede institutionaliserede man derimod en mere individuel fangebehandling - bl.a. i form af ungdomsfængsler og anstalter for psykisk syge forbrydere. ${ }^{53}$

Bruun nøjedes imidlertid ikke med at kritisere det fejlslagne system, men beskrev et konkret forslag til reformering af forbedringhusstraffen. Et system, der skulle give den indsatte lejlighed til at udvikle sig og dermed realisere en praksis, der i højere grad tog hensyn til individet. Forbilledet var det såkaldte progressive system, der byggede på en gradvis forbedring af fangen ved opstigning gennem en række klasser med tilhørende privilegier og udfordringer, hvoraf kun den første klasse byggede på fulstændig afsondring. Bruun ville således ikke fjerne afsondringen, men afkorte tiden i total isolation og udforme en straf, der lønnede initiativ og forberedte afsoneren bedre til den virkelige verden, der lå så uendelig langt fra tilværelsen i et cellefængsel som Vridsløselille.

Bruun havde allerede i årene forinden arbejdet internt via Justitsministeriet for denne reformering af cellestraffen og havde i forbindelse med iværksættelsen af den nye straffelov i 1866 faktisk vundet en delvis sejr i den henseende. På Bruuns initiativ havde man med straffelovsreformen indført en form for progressivt system i Vridsløselille i 1866. Det nye system gav fangerne en gradvis tildeling af begunstigelser og lønnede dermed det private initiativ. Isolationen gik man derimod ikke med til at indskrænke, som Bruun ellers havde anbefalet det. Heller ikke da det progressive system indførtes for alle landets straffeanstalter i $1873 . .^{54}$

\section{Fængselsvæsenets årsberetning 1868}

Året efter kritikken i Om Fuldbyrdelse af Strafarbeide udvidede Bruun sit angreb på cellestraffens daværende form i den obligatoriske femårs beretning for det danske fængselsvæsen (hvilken han forfattede som chef for Justitsministeriets fængselskontor). Her sattes fangernes "Uvirksomhedstilstand" i Vridsløselille direkte sammen med en række lidelser i anstalten: "Kongestioner til 
Hovedet, Svimmelhed, Susen for Ørene, Søvnløshed" og "Mangel paa Appetit". Det var ifølge beretningen alle symptomer, der i perioden 1863-68 havde vist sig i "stor Maengde og forøget Sygedagenes Antal" i fængslet. Langt værre var det dog, at disse lidelser udviklede sig til "en total Mangel paa Handlekraft og paa Villieenergi, til en aandelig og legemlig Slaphed ... som det enten lykkes at helbrede ved styrkende Medicin, Forandring $i$ og Forbedring af Kosten, lcengere Gaardtur eller lettere Arbeider i den fri Luft, eller som gaaer over til Tungsind og derfra til høiere Grad af Sindslidelse" ${ }^{55}$ Bruun beskrev således en form for personlig disintegration af de indsatte, hvor fysisk og åndelig sløvhed afløste almindelig menneskelig aktivitet. ${ }^{56}$

Man adresserede også det forhold, at nogle fanger efter længere tid nærmest vænnede sig til isolationens passivitet. Noget man i dag typisk ville tolke som et psykisk faretegn. Fra fængselsvæsenets side bemærkede man da også, at disse langtidsisolerede ikke just var håbefulde ved løsladelsen trods tilvænningen, men tværtimod var modløse og ængstelige og i et par tilfælde havde begået selvmord. $^{57}$

Om sløvheden og matheden konkluderedes det sammenfattende, at " af 100 Fanger, hvoraf $80 \%$ vare under 30 Aar, som i dette Tidsrum [1863-68] udholdt en Straffetid af indtil 3 Aar, tabte $57,3 \%$ i Vagt og $5 \%$ vare uforandrede. Af 52 Fanger, som hensade over 3 Aar (indtil 31/2 Aar), var der vistnok kun $40 \%$, som tabte $i$ Vagt, men af disse ... var der kun ganske enkelte, for hvem Straffen ikke paa enhver mulig Maade blev lindret, og dette uagtet var der kun 19 af dem, som forlode Anstalten i en nogenlunde normal Tilstand" ${ }^{58}$

Væsentligt mere end halvdelen af de langtidsisolerede var med andre ord stærkt skadede, selvom man havde kæmpet en hård kamp for at afbøde isolationens virkninger. Endvidere fortsatte man beretningen med nøje at beskrive de 27 såkaldte sværere anfald af sindssygdom, der havde været i Vridsløselille mellem 1863 og 1868.

\section{En psykiatrisk undersøgelse}

Bruuns hårde kritik - måske først og fremmest $\mathrm{i}$ form af den officielle beretning for fængselvæsenet - var sandsynligvis med til at fremprovokere politisk handling. Under alle omstændigheder kom problemerne i Vridsløselille til offentlighedens kendskab, og deres omfang gjorde det svært at sidde situationen overhørig. Fra Justitsministeriets side valgte man at lade en videnskabelig undersøgelse foretage. I 1871 forelå resultatet. En beretning med titlen Cellestraffens Indvirkning paa Forbrydernes mentelle Sundhedstilstand, forfattet af dr.med. Christian Tryde. Heri beskrev han en lang række tilfælde af sindssygdom, opstået $\mathrm{i}$ Vridsløselille, og diskuterede deres mulige årsag.

Materialet bestod i 45 optalte sindslidende fanger i de fem år mellem $1863 \mathrm{og}$ 1868. I denne periode hensad $i$ alt 1523 fanger i fængslet, hvorfor $i$ alt $2,9 \%$ således frembød sindssygdom..$^{59}$ Tilfældene af sindssygdomme i fængslet ind- 
deltes i tre grupper: De hvor sygdommen var et led i en anden legemlig sygdom, de hvor anfald $i$ fængslet skyldtes en kronisk hjernelidelse, og de som fandtes hos fanger, der slet ikke medbragte nogen kronisk lidelse til straffeanstalten ${ }^{60}$

Tryde var yderst varsom med at tildele cellestraffen og isolationen skylden for tilfældene af sindssygdom. Med stor finurlighed blev flere tilfælde kategoriseret $\mathrm{i}$ den anden gruppe, hvor sindssygdommen nok var blevet synlig i Vridsløselille, men i virkeligheden eksisterede i forvejen - i hvert fald som et potentiale. Tidens biologiske forestillinger kunne understøtte dette synspunkt. F.eks. anførte Tryde, at hjernen hos forbrydere allerede ved fødslen var "betynget med sygelige Anlag som Arv fra en vanslagtet Familie". ${ }^{61}$ Endvidere henførte Tryde gerne de fanger, der i fængslet tidligt viste tegn på sindsforvirring til de kronisk sindssyge og tog ikke hensyn til, at isolationen måske kunne indvirke hurtigt på raske individer. De såkaldte akutte udbrud, der ifølge Tryde ledsagedes af mathed, vægttab, melankoli og hallucinationer og ofte opstod i løbet af afsoningens første halvår, rubriceredes således i gruppen af kroniske lidelser. ${ }^{62}$ Et andet problem var det endvidere, at en del indsatte onanerede, hvilket angiveligt kunne medføre sindssygdom.

Tryde vægrede sig derfor stærkt ved, at udpege cellestraffen som den væsentligste synder. En del af de 3\% kunne således forklares på anden vis. Alligevel konkluderedes det, at isolationsfængslingen ikke kunne "siges fri for at virke skadeligt paa Forbryderens mentelle Sundhedstilstand". ${ }^{63}$

Flere af Trydes kollegaer, der arbejdede på landets sindssygehospitaler, var mere håndfaste i deres konklusioner. I de tilfælde, hvor en overflyttet indsat blev erklæret rask og skulle tilbage og afsone resten af sin straf, frarådede flere i hvert fald direkte, at man genoptog isolationen. En læge ved sindssygeanstalten i Vordingborg fremhævede i forbindelse med en indlagt fange eksempelvis " $d e t$ sandsynlige $i$, at Celleisolationen har havt, den vasentligste Andel" i sindssygdommen. ${ }^{64}$ Typisk overførte man sådanne tilbagevendende fanger til fællesarbejde ved straffeanstalten på Christianshavn.

\section{Masturbation og mentale problemer}

Som allerede illustreret, var man i Vridsløselille tidligt opmærksom på, at ensomheden var en mulig årsag til forstyrrelser og sindssygdom. Men andre forklaringsmuligheder lå også åbne. Bl.a. kunne den mandlige seksualdrift være et oplagt mål for fængslets opmærksomhed. Mere præcist så man i onanien en fare for de indsattes helbred og en mulig forklaring på tilfældende af sindssygdom. Dr. Tryde mente således, at der kunne være en sammenhæng mellem masturbation og "Forstyrrelser i Hjernevirksomheden". Det var igen tidens biologiske tænkning, der satte sit fingeraftryk på psykiaterens arbejde. ${ }^{65}$

Som nævnt ovenfor, inddelte Tryde tilfældene af sindssygdom i Vridsløselille $\mathrm{i}$ tre grupper. Om den sidste gruppe - hvor sindssygdomen først opstod i fængslet - hed det, at "de paagjaldende Fanger vare alle unge og ugifte, og havde 
gjennemgaaende $i$ høi Grad voret hengivne til Onani" ${ }^{66}$ Der var blandt disse indsatte tale om "sindssyge Symptomer" af en meget fremtrædende beskaffenhed, der ifølge Tryde i vid udstrækning stemte overens med følgerne af hyppig masturbation. Symptomerne begyndte ofte som mindre forbigånde anfald af dvaskhed, arbejdsvægring, blodstigning til hovedet, søvnløshed, ængstende drømme, og ledsagedes sidenhen af mistænksomhed, pirrelighed, lunefuldhed og "høie Begreber om egen Dygtighed". En trykket stemning hos onanisten kunne nu bevæge sig over i svagere eller stærkere perioder af opstemthed, der gik hånd $\mathrm{i}$ hånd med lette hallucinationer og undertiden forvirrede ytringer og handlinger. Greb man ikke ind, ville tilstanden udvikle sig og medføre hukommelsestab samt mere iøjnefaldende sindslidelser. ${ }^{67}$

At personalet i Vridsløselille mente, at det kunne være relevant at bemærke udskejelser i de mandlige fangers seksualitet, findes der da også eksempler på. Om en brystsvag indsat, der i 1861 led af mathed og tiltagende afkræftelse, noterede man således, at han selv erklærede at være onanist. ${ }^{68}$ En anden fange klagede direkte over, at man mistænkte ham for at være onanist, hvilket han ifølge fængslets papirer " $i$ Virkeligheden ogsaa var". Den pågældende blev senere stærkt mistroisk, hallucinerede voldsomt og talte "aldeles forstyrret", hvorefter man fra fængslets side afleverede ham til en sindssygeanstalt. ${ }^{69}$

I det hele taget blev flere observationer af onani nedfældet i fængslets papirer. Der var altid tale om relativt kortfattede notater, som i tilfældet Gustaf Svensson. Om denne 19-årige svensker, bemærkede fængselslægen tørt: "Det er bemcerket at han onanerer". At man tillagde svenskerens last en sundhedsmæssig betydning fremgår af en senere tilføjelse i sygejournalen. Svensson havde således et meget "sygeligt og enerveret Udseende" samt hjertebanken og var "medtaget af Onani". ${ }^{70}$

Inspektør Bruun var da heller ikke i tvivl om, hvordan tingene kunne hænge sammen. Om onani i isolationsfængsler konstaterede han følgende:

"At livskraftige Mennesker i deres bedste Alder, der ikke overanstrenges ved Arbeide, der have havt Hang til Sandselighed, men manglet Selvbeherskelse og Kraft til at tvinge deres Tilbøieligheder, at de ikke mere end almindelig skulde fristes til denne Last af Ensomhedens grasselige Monotoni, derom naerer jeg for min Del ingen Tvivl, ligesom jeg ogsaa efter mine Erfaringer er overbeviist om, at denne Last mere $i$ Cellefangslet end i noget andet Fangsel, navnlig hos de Yngre, nedbryder de aandelige og legemlige Krafter og fører ad den korteste Vei til Hallucinationer og Sindsrystelser. At Aarsagen til ikke faa af Sindssygdomme [ne] $i$ Vridsløse Fangsel maa hentes herfra, anser jeg som afgjort". ${ }^{71}$

At man på denne måde - både hos fængslets ledelse og og den psykiatriske ekspertice - kunne finde sindssygdommens årsag i de indsattes seksuelle udfoldelser, var naturligvis med til at forvirre situationen og frikende ensomheden. Selvom Bruun kædede de to ting sammen, så kunne debatten om sindssygdom for tilhængere af cellestraffen ende i et spørgsmål om hvordan man skulle tæmme de syndige onanister. 


\section{Hvor mange syge?}

Det er et åbent spørgsmål, hvor mange der led under isolationen i Vridsløselille. De ovenfor skitserede tilfælde og komplikationer omhandler i reglen under halvdelen af de indsatte. Vægttabene omfattede ifølge de officielle rapporter knap halvdelen af fangerne, mens optællinger i sygejournalerne peger i retning af, at i hvert fald en tredjedel af de indsatte var mærket af isolationsfængslingen. ${ }^{72}$ I enkelte tilfælde bemærkedes dog en bedring, som i tilfældet 1274, der var svækket ved ankomsten, men ifølge lægen blev rask i fængslet. ${ }^{73}$ Alt dette betyder naturligvis ikke, at der ikke var langt flere der tog skade af afsondringen. Som allerede forklaret, så betød den biologiske opfattelse af sindssygdommen og manglende kendskab til ensomhedens følger, at man kunne have særdeles svært ved at identificere isolationssymptomer hos de indsatte. Opfattelsen af onanien som årsag til galskab er et glimrende eksempel på dette.

Endvidere taler meget for, at den tilbagetrækning og manglende lyst til social kontakt, der ramte mange isolerede, i Vridsløselille blev tolket som tilpasning til livet $\mathrm{i}$ fængslet - mens mange $\mathrm{i}$ dag vil tolke en sådan reaktion som et tegn på store psykologiske problemer, forårsaget af afsondringen.

Under alle omstændigheder er det givet, at et stort antal indsatte - omkring $3 \%$, jvf. Trydes rapport - blev utvetydigt sindssyge pga. isolationen, mens en langt større gruppe - mindst en tredjedel - led mærkbart under ensomheden, ofte både fysisk og psykisk. Sidstnævnte kan man som nævnt konstatere ved en optælling i sygejournalerne, hvor det ofte beskrives, når indsatte blev stærkt sløvet af afsoningen. Af denne gruppe må en tredjedel endvidere betegnes som alvorligere tilfælde. De blev beskrevet som eksempelvis meget sygelige af udseende, sindsforvirrede, hallucinerende, havende vrangforestillinger eller det konstateredes måske at de ikke kunne tåle ensomheden. Dette peger i retning af, at i hvert fald $12 \%$ af samtlige indsatte var påvirket af isolationen i alvorligere grad. ${ }^{74}$ Afgørende har det naturligvis været, hvor længe man har siddet i Vridsløselille. Bruun beskrev som tidligere omtalt, at af de langtidsisolerede var over halvdelen stærkt påvirkede og de resterende blot "nogenlunde" normale.

Ser man bort fra de fanger, man i fængslet stemplede som egentlig sindssyge, så var der blandt den optalte tredjedel mange, der i dag ville blive betegnet som regulært vanvittige. Det vidner bl.a. sporadiske beretninger inden for fængslets mure om. Der befandt sig efter alt at dømme til hver en tid et væsentligt antal decideret vanvittige indsatte i fængslet. Forskellige former for besynderlig opførsel ledte som allerede illustreret ikke nødvendigvis til overflytning til et sindssygehospital. Det havde jo heller ikke set godt ud i årsberetningerne, som den indsatte socialist Louis Pio pointerede, hvis alle indsatte, der blev "mere eller mindre afsindige ved Ensomheden", blev overflyttet til sindssygehospitaler. Pio lå selv på fængslets sygestue og kaldte denne "et lille privat Galehus", der skulle tage brodden af de værste tilfælde. De "rolige Fjollede" der "kun har Hallucinationer eller lider af enkelte fikse Ideer" fik ifølge Pio lov til at blive i 
deres celler, hvor man ved hyppige besøg forsøgte at "holde den gaaende". ${ }^{75}$

Pios teori er tilsyneladende korrekt - selvom den pga. isolationen naturligvis ikke bygger på direkte observation (sygestuen undtaget). Alligevel stemmer den godt overens med fængslets arkivmateriale, der peger i retning af, at det var de problematiske individer snarere end de psykisk syge $\mathrm{i}$ al almindelighed, der overflyttedes til sindssygehospitaler. Af Wibergs rapporter kan man konstatere, at en del behandledes for sindsforvirring og lignende både i cellerne og på sygestuen. Jævnfør Pios beskrivelse så optog de sindsforvirrede ofte megen plads på fængslets eget lille hospital. I finansåret 1864-65 udgjorde de eksempelvis den næststørste sygdomsgruppe efter fnat. Seks var således sindsforvirrede, mens en i øvrigt led af galskab. Året efter var billedet det samme med syv sindsforvirrede, omend der var et tilsvarende antal febertilfælde (hertil kommer de, der behandledes for sindsforvirring eller lignende i deres celler) ${ }^{76}$ Dette skal vel og nærke ses i lyset af de mange sygdomme, der på årsbasis ramte de flere hundrede fanger, der passerede gennem fængslet - dækkende alt fra hoste og brystsyge til benskader og syfilis.

Sammenfattende må man konkludere, at en stor gruppe indsatte tog anseelig skade af den afsoning, der ellers var designet til at forbedre dem. Sigende er naturligvis inspektør Frederik Bruuns egen holdning til sagen. Han havde igennem en årrække haft livet i Vridsløselille inde på livet og var, som allerede beskrevet, ikke i tvivl om, hvor skadelig isolationen var.

\section{Den sejlivede isolationspraksis}

Det klassementsystem, man på Bruuns foranledning indførte i Vridsløselille i 1866, dannede rammen omkring indførelsen af det progressive system $i$ alle landets straffeanstalter i 1873. Men heller ikke ved denne lejlighed skar man ned på isolationen, som man ønskede den udført i forbindelse med forbedringshusstraffen, der på dette tidspunkt blev gennemført i eneceller i Vridsløselille, i straffeanstalten på Christianshavn og 1870 til 1875 også i Viborgs gamle fængsel. Tværtimod blev ensomheden intensiveret en anelse med reglementet af 1866 - stik imod Bruuns oprindelige hensigt. I forsøget på at belønne fangens initiativ ved at lade privilegier følge med opstigningen i klasse fjernede man en række muligheder for de nyankomne indsatte. I 1 ste klasse måtte man eksempelvis ikke låne bøger fra fængselsbiblioteket og måtte kun modtage undervisning i cellen, mens man var nægtet adgang til fangeskolen. Under de første tre måneder i Vridsløselille blev isolationen således endnu strengere.

Den totale afsondring blev der i det hele taget ikke gjort op med, og rent faktisk levede isolationsprincipperne i bemærkelsesværdig grad videre i Danmark. Ved fængselskonstruktioner i 1890'erne var afsondring og såkaldte panoptiske overvågningsprincipper stadig i højsædet. ${ }^{77}$ Først fra og med 1924 var de indsatte i Vridsløselille ikke længere tvunget til at bære masker, omend de stadig gerne måtte $!^{78}$ Maskerne var imidlertid for længst blevet afskaffet de fleste steder i 
udlandet. Erik Kampmann kunne i starten af 1930'erne fastslå, at cellestraffen i Vridsløselille endnu gennemførtes " $i$ det vasentlige $i$ den samme 'klassiske" Skikkelse som oprindelig". ${ }^{79}$ Det mere end 70 år efter Vridsløselilles åbning.

Omtrent samtidig foretog man dog et opgør med isolationsprincippet. I perioden 1932-34 byggede man eksempelvis Vridsløselilles panoptiske skole og kirke om, så hver enkelt indsat nu ikke sad isoleret, men i et reelt fællesskab kunne deltage i undervisning og gudstjeneste. ${ }^{80} \mathrm{I}$ udlandet betragtede de fleste i denne periode dansk straffepraksis som oplyst og moderne, men man bed mærke i, at isolationsprincippet var sejlivet. Danmark måtte eksempelvis i 1929 lægge ryg til international kritik på denne konto, præcis som det har været tilfældet $\mathrm{i}$ 1990'erne. I et internationalt tidsskrift skrev E. Roy Calvert således en mindre artikel under overskriften "Prisons of Denmark", hvori han noterede at danskerne snart måtte lære "the bitter lesson", at isolation er skadelig for fangerne. ${ }^{81}$

Man havde ellers igen i starten af 1900-tallet fra Justitsministeriets side ladet en undersøgelse af Vridsløselille foretage - herunder spørgsmålet om isolationens skadevirkning. Lægen George E. Schrøder, der i 1913 havde forfattet Fangselspsychoser og Psychoser i Fangslet, fik dette opdrag. I 1917 forelå resultatet i form af Psykiatrisk Undersøgelse af Mandsfanger i Danmarks Straffeanstalter. Heri konkluderedes det "om isolationens indflydelse på sjaclelivet", at "der ikke ses skadelige følger hos i forvejen sjalssunde mennesker".

Men Schrøder var om muligt endnu mere indsyltet i den tidligere omtalte biologiske tænkning, der i denne periode stadig stod overordentligt stærkt internationalt. Der var ifølge Schrøder således individer, der ikke kunne udstå isolationen, men årsagerne var biologiske. Eksempelvis tålte "de degenererede fantaster" i de fleste tilfælde ikke cellestraffen, mens også paranoide karakterer fik problemer i ensomhed. Ligeledes ville "de hysterisk anlagte" (der hørte under de "Psykopathisk" degenererede og dermed biologisk syge) ofte udvikle en fængselspsykose under indespærring. ${ }^{82}$ Grundet disse gruppers angivelige patologiske karakter mente den psykiatriske ekspert, at det var forsvarligt at forlænge cellestraffen - dvs. isolationsfænglingen - hvilket var til politisk debat $\mathrm{i}$ 1917.

Men selv Schrøders undersøgelse skulle ikke blive den sidste, og i 1990 gentog Justitsministeriet sin anmodning - tilsyneladende fuldstændig uvidende om, at samme opgave var udført to gange tidligere, og at man havde særdeles omfattende erfaringer i Danmark netop med den totale afsondring af indsatte. Baggrunden for 1990 undersøgelsen var isolationsfængsling i forbindelse med varetægt i det 20'ende århundrede. En praksis der længe har været opretholdt i Danmark og set på baggrund af erfaringerne fra Vridsløselille har haft et særdeles uheldigt omfang. ${ }^{83}$ 


\section{NOTER}

1 Landsarkivet for Sjælland m.m. (LAK), Vridsløselille statsfængsel (VS), journalsag nr. 89/6768, samt Chr. Tryde Cellestraffens Indvirkning paa Forbrydernes mentelle Sundhedstilstand 1871, s. 23 f. Se i øvrigt Frederik Bruun Beretning fra kontoret for Fangselsvaesenet om Straffeanstalternes Tilstand i Tidsrummet fra 1ste Januar 1858 til 31te Marts 1863 1868, s. 105.

$2 \quad$ Peter Scharff Smith "For fangens elementaire moralske opdragelse. Rationalitet, religion og modernitet set i lyset af det moderne fængselsvæsens gennembrud" i Historisk Tidsskrift, bd. 101, hft. 2, 2001, s. 345- 392.

Smith 2001.

4 Peter Scharff Smith "Det moderne fængselsvæsens gennembrud i Danmark. Opdragelse, moral og fængselskommissionen af 1840" i Fortid og Nutid, nr. 2, 2002, s. 103-133.

Bruun 1868, s. 90.

Rigsarkivet (RA), DK, 3 dep., udg. breve, nr. 2513, Fængselskommissionens beretning, s. 83.

Tidligere rapporter er i hvert fald ikke bevaret $\mathrm{i}$ arkivet.

8 De bogførtes dog i den forstand, at man summarisk noterede hvilke fanger der rykkede en klasse op eller en klasse ned, samt hvilke der ankom og blev løsladt.

9 Se LAK, VS, Forhandlingsprotokol, d. 6/1 1860, LAK, VS, stamrullen nr. 27/59 og LAK, VS, Forhandlingsprotokol, d. 13/1 1860.

10 LAK, VS, Forhandlingsprotokol, d. 9/3 1860. Kragh er sandsynligvis fange nr. 34, Jens Faber Lihme Kragh, der ankom med de første fanger d. 20. december 1859. Kraghs sundhedstilstand var da god, jvf. LAK, Vridsløselilles arkiv, stamrullen nr. 50/59.

LAK, VS, Forhandlingsprotokol, d. 3/10 og 24/10 1860.

Ibid., 4/1 1861.

LAK, VS arkiv, journalsag nr. 183a/61-62.

LAK, VS, journalsag nr. 183b/61-62.

LAK, VS, journalsag nr. 183c/61-62.

“... og hvad der er anført om Mathed og Svakkelse var kun hos Faae og af ringe Betydning”. LAK, Vridsløselille Statsfængsels arkiv, journalsag nr. 183d/61-62. Årsrapport 1861-62.

17 LAK, VS, journalsagerne nr. 82 og 83/61-62.

18 LAK, VS, journalsag nr. 312/62.

19 LAK, VS, journalsag nr. 312/62,

20 LAK, VS, journalsag nr. 115/62-63, brev forfattet af Wiberg d. 14/9 62 om Hans Jensen, samt journalsag nr. 312/62.

LAK, VS, journalsag nr. $106 \mathrm{a}+\mathrm{b} / 62-63$.

LAK, VS, journalsag nr. 20/63-64.

LAK, VS, journalsag nr. 101/63.

24 De fleste undersøgelser af isolationsfængsling melder om forskellige (især psykiske) skadevirkninger. Se f.eks. Isolationsundersøgelsen 1994 og Efterundersøgelsen 1997 begge af Henrik Steen Andersen, Tommy Lillebæk og Dorte Sestoft, samt Ida Koch "Isolationens psykiske og sociale følgevirkninger" i Søren Ganes m.fl. (red.) Umenneskelighedens ansigter. Temabog om tortur, dødstraf, isolationsfangsling og Amnesty Internationals lagegrupper 1983 og Stuart Grassin "Psychopathological Effects of Solitary Confinement" i American Journal of Psychiat$r y$ vol 140, nr. 2, 1983.

25 LAK, VS, journalsag nr. 2/64.

26 LAK, VS, journalsag nr. 157/63.

27 Bruun 1864, s. 45

28 Fra sidst i 1840'erne havde man dog begrænsede forsøg med eneceller i straffeanstalten på Christianshavn, der imidlertid på ingen måde fungerede som det panoptiske Vridsløselille.

29 Christian Graugaard og Preben Hertoft "Hjerne \& sexuel afvigelse - historiske og moderne nedslag" i Psyke og Logos, vol. 18, 1997, s. 438 f. 
Se f.eks. J.C. Prichard (ved Harald Selmer) Om Sindssygdommene og andre sygelige Sjelstilstande 1842. Se i øvrigt Peter Scharff Smith Moralske hospitaler - Det moderne fangselsvaesens gennembrud internationalt og i Danmark ca. 1770-1870. Ph.d. afhandling, Københavns Universitet 2002, s. 198 ff.

Bruun 1868, s. 93.

Smith 2002, s. 209 f. Her beskrives også andre fysiologiske reaktioner.

Se bl.a. LAK, VS, Journalsag nr. 50/65, samt 137/67-68.

LAK, VS, Journalsag nr. 5/67-68, samt Tryde 1871, s. 10.

LAK, VS, Journalsag nr. 10/67-68.

LAK, VS, Sygejournalen nr. 2576.

LAK, VS, Sygejournalen nr. 2600.

Se eksempelvis LAK, VS, Journalsag nr. 27/65, Wibergs rapport for finansåret 1864-65.

LAK, VS, Journalsag nr. 89/67-68.

LAK, VS, Journalsag nr. 5/67-68, samt Tryde 1871, s. 9.

LAK, VS, Journalsag nr. 89/67-68.

LAK, VS, Sygejournalen nr. 1260.

Tryde 1871, s. 18.

LAK, VS, Journalsag nr. 157/63, Wibergs rapport for finansåret 1863-64.

LAK, VS, Sygejournal 1868-69, nr. 1222 (2086).

LAK, VS, Sygejournal 1869-70, nr. 2505.

Bruun 1867, s. 59.

Bruun 1867, s. 48.

Bruun 1867, s. $50 \mathrm{f}$.

Bruun 1867, s. 53.

Bruun 1867, s. $54 \mathrm{ff}$.

Bruun 1867, s. $60 \mathrm{ff}$.

David Garland Punishment and Welfare 2001 (1985), se bl.a. s. 14 og 31 f.

54 Erik Kampmann: "Fængselsvæsenets udvikling gennem tiderne" i Christian Gjerløv (red.)

Dansk Politistat 1934., s. 117 ff.

Bruun 1868, s. 95 f.

Præcis som Ida Koch har anført det i sine undersøgelser. Se bl.a. Koch 1983, s. $118 \mathrm{ff}$.

Bruun 1868, s. 96.

Bruun 1868, s. 97.

Tryde 1871, s. 5.

Tryde 1871 , s. $58 \mathrm{f}$.

Tryde 1871, s. 38.

Tryde 1871 , s. $58 \mathrm{f}$.

Tryde 1871, s. 94.

LAK, VS, Journalsag nr. 4/66-67.

Jvf. blandt andre René A. Spitz "Authority and Masturbation" i The Psychoanalytic Quarterly, vol. $21,1952$.

Tryde 1871, s. 59.

Tryde 1871, s. 61.

LAK, VS, Forhandlingsprotokol 1859-68, d. 4/12.

Bruun 1868, s. $102 \mathrm{f}$.

LAK, VS, Sygejournal 1868-69, nr. 1253.

Bruun 1867, s. 57.

72 Optælling i sygejournalerne 1868-69 og 1869-70 af 300 tilfældigt udvalgte indsatte. I alt 102 dvs. omtrent en tredjedel - blev beskrevet som mærket af straffen, f.eks. som meget matte og trætte, medtagne, svagelige og måske også søvnløse, blege, afmagrede og deprimerede etc. Af disse må 36 betegnes som alvorligere tilfælde. Dvs. $12 \%$ af den samlede fangemasse havde jvf. denne optælling alvorligere isolationssymptomer. 
73 LAK, VS, Sygejournal 1868-69 nr. 1274.

74 LAK, VS, Sygejournalerne 1868-69 og 1869-70. Optælling af 300 tilfældige fanger. Se note ovenfor.

75 Pio Erindringer fra Redaktionskontoret og Fangslet, København 1975 (1877), s. 68.

76 LAK, VS, Journalsag nr. 27/65, Wibergs rapport for finansåret 1864-65, samt journalsag 35/6667, Wibergs rapport for finansåret 1865-66.

77 F.eks. ved opførelsen af Vestre fængsel i 1895, se Erik Carlé Københavns fangsler i 100 år, Nyborg 1995. Bl.a. opførte man også her såkaldte strålegårde. Vedr. isolationens betydning, se i øvrigt s. $41 \mathrm{f}$.

78 Vagn Kildemoes Statsfaengslet i Vridsløselille 1959, s. 22 f.

79 Kampmann 1934, s. 119. I 1913 havde man dog foretaget visse ændringer i cellestraffen udenfor Vridsløselille. I forbindelse med oprettelsen af Nyborg statsfængsel videreudviklede man det progressive system, og gjorde det nu muligt - som oprindeligt anbefalet af Bruun - at lade fangerne overgå til fællesskab allerede fra det såkaldte mellemstadie.

80 Kildemoes 1959, s. 17.

81 E. Roy Calvert "Prisons of Denmark" i Howard Journal, juni 1929, s. 301-306, her citeret efter Negley K. Teeters World Penal Systems. A Survey 1944, s. 89.

82 Schrøder 1917, s. 262.

83 Antallet af isolerede er dog faldet mærkbart inden for de senere år - efter lovændringen der trådte i kraft 1/7 2000. Man har endvidere indført en principiel 3 måneders grænse for isolationen. Det er dog stadig muligt at isolere for de alvorligste forbrydelser ud over 3 måneder. Der eksisterer således ingen egentlig maksimumsgrænse.

\section{Adresse: Glostorp Kyrkoväg 15 SE - 23841 Oxie}

